\title{
Genotypic Variations in Phenolic, Flavonoids and Their Antioxidant Activities in Maize Plants Treated with Zn (II) HEDTA Grown in Salinized Media
}

\author{
Zeinab A. Salama1 ${ }^{*}$, Alaa A. Gaafar ${ }^{1}$, Mohamed M. El Fouly ${ }^{2}$ \\ ${ }^{1}$ Department of Plant Biochemistry, National Research Centre (NRC), 33 EL Bohouth st. (former EL Tahrir st.), \\ Dokki, Giza, Egypt \\ ${ }^{2}$ Department of Fertilization Technology, National Research Centre (NRC), 33 EL Bohouth st. (former EL Tahrir \\ st.), Dokki, Giza, Egypt \\ Email: "dr.zeinabsalama70@gmail.com
}

Received 6 March 2015; accepted 24 March 2015; published 30 March 2015

Copyright @ 2015 by authors and Scientific Research Publishing Inc.

This work is licensed under the Creative Commons Attribution International License (CC BY). http://creativecommons.org/licenses/by/4.0/

(c) $\stackrel{\text { () }}{\text { EY }}$ Open Access

\section{Abstract}

Zinc (Zn (II) HEDTA) was used to determine their effect on salt-induced damages in maize plants. The aim of this study was to investigate the antioxidant capacity and the levels of enhanced total phenolic (TPC), total flavonoid (TFC) contents and their antioxidant activity in leaves of two maize cultivars Single cross 10 (SC10) and Single cross 162 (SC162) grown in two levels of salinity 0.00 and $100 \mathrm{mmol}$ in response to $20 \mu \mathrm{mol} \mathrm{Zn}$ (II) HEDTA foliar spray treatments. Significant differences $(P \leq 0.05)$ in amounts of TPC ranged from $(2.55$ to $4.62 \mathrm{mg} / \mathrm{gdw}$ as Gallic) in Single cross 10 (SC10) and from (2.53 to $4.38 \mathrm{mg} / \mathrm{gdw}$ as Gallic) in Single cross 162 (SC162), TFC (ranged 1.53 to $2.41 \mathrm{mg} / \mathrm{gdw}$ as qurestien) in Single cross 10 (SC10) and from (1.28 to $2.41 \mathrm{mg} / \mathrm{gdw}$ as qurestien) in Single cross 162 (SC162) among all treated plants were observed. The levels of their compounds increase related to foliar spraying of Zn (II) HEDTA. A significant positive correlation between TPC, TFC and DPPH scavenging activity and iron chelating activity was observed which shows that phenolic compounds were involved in the mechanism of salt tolerance of the two cultivars by showing enhanced antioxidant activity which resulted in reduced membrane damage and hence improved growth. According to the results obtained, the adverse effects of salt stress on maize plants can partly be alleviated with application of Zn (II)-HEDTA chelates. It is concluded that the application of Zn (II) HEDTA to maize plants grown in salt conditions leads to the increase of antioxidant compounds and maize tolerance.

\footnotetext{
${ }^{*}$ Corresponding author.
}

How to cite this paper: Salama, Z.A., Gaafar, A.A. and El Fouly, M.M. (2015) Genotypic Variations in Phenolic, Flavonoids and Their Antioxidant Activities in Maize Plants Treated with Zn (II) HEDTA Grown in Salinized Media. Agricultural Sciences, 6, 397-405. http://dx.doi.org/10.4236/as.2015.63039 


\section{Keywords}

\section{Salinity, Phenolics, Flavonoids, Zn (II) HEDTA, Maize Crosses}

\section{Introduction}

Salinity is one of the most important abiotic stresses affecting yield and quality of agricultural plants worldwide. Salinity may affect root uptake, translocation to shoots and physiological utilization of nutrients in plant. For example, [1] reported that reduced phytosiderophore exudation from roots of Fe and $\mathrm{Zn}$ deficient barley plants under salinity conditions that decreased root Fe and Zn uptake Fe, Zn, Mn foliar spray used by [2] [3] to increase wheat tolerance in wheat plants.

To reduce AOS-induced damage, plants have evolved an antioxidative system, involving antioxidative enzymes, as well as low-molecular mass secondary metabolites such as phenolic compounds [4]. However a lot of research is being conducted to elucidate the role of various antioxidant metabolites in plant stress tolerance, antioxidant properties of phenolic compounds among other metabolites have been studied to a great extent [5] [6]. Higher activity of phenolics under stress conditions could be due to the greater $\mathrm{H}^{+}$-donating ability and radical stabilization than a variety of other antioxidant metabolites [7]. However, zinc possesses significant antioxidant activity, which implies the potential for utilizing and promoting the health benefits of maize [8] [9]. Phenolic and flavonoids are the main antioxidant compounds that are believed to be responsible for the antioxidant properties [10] [11]. Different plant species and genotypes within a species respond differently to salt stress. Maize (Zea mays L.) is the third most important cereal crop after wheat and rice and is grown all over the world in a wide range of climatic condition. Being highly cross pollinated, maize has become highly polymorphic through the course of natural and domesticated evolution and thus contains enormous variability in which salinity tolerance may exist. Maize (Zea mays L.) is moderately sensitive to salinity and considered as salt sensitive of cereals [8]. Despite its position, as one of the leading food crops of the world, few findings have been done to improve salt tolerance in this crop. Because of great sensitivity of this crop, improvement for salt tolerance would be of considerable value.

Zinc (Zn) is an important micronutrient essential for plant growth and development. One approach is the use of foliar spraying for increasing plant tolerance to salinity by alleviating $\mathrm{Na}^{+}$and $\mathrm{Cl}^{-}$injury to plants [12]-[14]. So, the objective of the present work was to examine the pattern of accumulation of phenolic contents in response to Zn-HEDTA foliar spray in two maize cultivars under salt stress, and the roles of these phenolic compounds in plant tolerance, because it is known that different antioxidant compounds may act in vivo through different mechanisms, in plant stress tolerance.

\section{Materials and Methods}

\subsection{Plant Materials and Growth Conditions}

The experiment was carried out at Fertilization Technology Department, National Research Centre, Cairo, Egypt, at Climatic Chamber (SNIJDERS SCIENTIFIC) donated by A.V. Humboldt Foundation, FR Germany. Seeds of two cultivars of maize Single cross 10 (SC10) and Single cross 162 (SC162) were washed and soaked for several hours in aerated tap water. The germination was carried out in plastic dishes at $28^{\circ} \mathrm{C}$ in dark. Three days-old seedlings were put to grow in plastic pots filled with one-tenth concentration of Hoagland-Arnon solution ( $\mathrm{pH}$ 6.0) containing $5 \mathrm{~m} \mathrm{MCa}\left(\mathrm{NO}_{3}\right)_{2} \cdot 4 \mathrm{H}_{2} \mathrm{O}, 5 \mathrm{mM} \mathrm{KNO}_{3}, 1 \mathrm{mM} \mathrm{KH}_{2} \mathrm{PO}_{4}, 2 \mathrm{mM} \mathrm{MgSO}_{4} \cdot 7 \mathrm{H}_{2} \mathrm{O}$ and micronutrients in $\mu \mathrm{M}: \mathrm{H}_{3} \mathrm{BO}_{3}-10, \mathrm{MnCl}_{2}-0.5, \mathrm{ZnSO}_{4}-0.5, \mathrm{CuSO}_{4}-0.2, \mathrm{Na}_{2} \mathrm{MoO}_{4}-0.1$, Fe (III)-HEDTA-20. The seedlings were grown in an environmental chamber under 12-h light at PPFD of $120 \mu \mathrm{mol} \cdot \mathrm{m}^{-2} \cdot \mathrm{sec}^{-1}$ provided by fluorescent tubes, 12 -h night, $60 \% \mathrm{RH}$, at $25^{\circ} \mathrm{C}$ day $/ 20^{\circ} \mathrm{C}$ night temperature. Two days later the plants were divided into four variants (plus and minus $\mathrm{NaCl}$ ) with and without spraying Chelated $\mathrm{Zn}(20 \mathrm{umol})$ were applied for each pot. It was used to correct the nutrient imbalance caused by salt stress conditions. At 21 days old leaves were collected for different analysis.

\subsection{Chemicals}

2,2-Diphenyl-1-picrylhydrazyl (DPPH) was purchased from Sigma Aldrich from Sigma-Aldrich (St. Louis, 
MO). 3-(2-Pyridyl)-5,6-diphenyl-1,2,4-triazine-4',4"-disulfonic acid monosodium salt (ferrozine) were purchased from Fluka (Buchs, Switzerland). All other chemicals and solvents were of the highest commercial grade and obtained from Sinopharm Chemical Reagent Co. Ltd. (Shanghai, China).

\subsection{Biochemical Analysis}

\subsubsection{Determination of Total Phenolic Content (TPC)}

The total phenolic content (TPC) in maize extracts were determined spectrophotometrically according to [15] by Folinn-Ciocalteu reagent assay using Gallic acid as a standard compound for the preparation of calibration curve (20 - $120 \mu \mathrm{g} / \mathrm{ml}$ ). (Total phenolic content of samples was measured at $670 \mathrm{~nm}$ and expressed as $\mathrm{mg}$ Gallic acid equivalents (GAE)/g dry weight. All samples were analyzed in triplicates.

\subsubsection{Determination of Total Flavonoids (TFC)}

Total flavonoids content (TFC) of maize extracts were spectrophotometrically determined by the aluminum chloride method using quercetin as a standard compound for preparation of calibration curve based on the formation of complex of flavonoid aluminum [16]. After incubation at room temperature samples were measured at $512 \mathrm{~nm}$ and expressed as mg quercetin equivalents $(\mathrm{QE}) / \mathrm{g}$ fresh weight. The content of flavonoids was also estimated from the standard calibration curve of (20 - $120 \mu \mathrm{g} / \mathrm{ml})$ Samples were analyzed in triplicates.

\subsubsection{DPPH· Free Radical Scavenging Assay}

The method described by [17] was used to assess the DPPH' (2, 2-diphenyl-1-picryl hydrazyl) radical scavenging activity of maize methanolic extract. $0.1 \mathrm{mmol}$ of DPPH in methyl alcohol was prepared and $0.5 \mathrm{ml}$ of this solution was added to $1 \mathrm{ml}$ of maize methanolic extracts at different concentrations (20, 50, 100, 150, 200 $\mu \mathrm{g} / \mathrm{ml}$ ). Methanol was used as blank. The mixture was shaken vigorously and allowed to stand at room temperature. Butyl Hydroxy toluene (BHT, Sigma) was used as positive control; and negative control contained the entire reaction reagent except the extracts. Then the absorbance was measured at $515 \mathrm{~nm}$ against blank (methanol pure). Lower absorbance of the reaction mixture indicated higher free radical scavenging activity.

The capacity to scavenge the DPPH' radical was calculated using the following equation:

DPPH' scavenging effect (Inhibition \%) =

$$
\left[\left(A_{c}-A_{s} / A_{c}\right) \times 100\right]
$$

where $A_{c}$ was the absorbance of the control reaction and as the absorbance in the presence of the plant methanolic extract.

\subsubsection{Metal Chelating ACTIVITY}

Metal chelating effects on ferrous ions was carried out as described by [18]. One $\mathrm{ml}$ of $80 \%$ maize methanolic extract, or EDTA solution as a positive control at different concentrations $(20,50,100,150,200 \mu \mathrm{g} / \mathrm{ml})$ were spiked with $0.1 \mathrm{ml}$ of 2 mmol FeCl $2-4 \mathrm{H}_{2} \mathrm{O}$ and $0.2 \mathrm{ml}$ of $5 \mathrm{mmol}$ ferrozine solution and $3.7 \mathrm{ml}$ methanol were mixed in a test tube and reacted for $10 \mathrm{~min}$, at room temperature then the absorbance was measured at $562 \mathrm{~nm}$. Mixture without extract was used as the control. A lower absorbance indicates a higher ferrous ion chelating capacity.

The percentage of ferrous ion chelating ability was calculated using the following equation:

Iron chelating activity (Inhibition \%) =

$$
\left[\left(A_{c}-A_{S} / A_{c}\right) \times 100\right]
$$

where $A_{c}$ was the absorbance of the control reaction and As the absorbance in the presence of the plant methanolic extract

\subsection{Statistical Analysis}

Data were statistically analyzed according to [19]. 


\section{Results and Discussion}

\subsection{Effect of Salinity on (TPC) and (TFC) and Their Antioxidant Activities on Two Maize Cultivars Spraying with Zn (II) HEDTA}

Data presented in Table 1 and Table 2 showed the amounts of total phenolic content (TPC) and total flavonoids content of two maize cultivars grown in $100 \mathrm{mmol} \mathrm{NaCl}$ or without $\mathrm{NaCl}$ ) in response to Zn (II) HEDTA foliar spray. The concentration of these components in leaves of two cultivars showed a significant difference $(\mathrm{P}<$ 0.05) among all treatments. $100 \mathrm{mmol} \mathrm{NaCl}$ caused significant increase in accumulation of TPC and TFC. The levels of those compounds being about (6.05.4.38 mg G/gdw) and (2.8 and $3.06 \mathrm{mg} \mathrm{Q} / \mathrm{gdw}$ ) for both cultivars respectively, as high as that in leaves of plants grown without $\mathrm{NaCl}$. Thus, $\mathrm{NaCl}$ increased concentration of low molecular mass antioxidant compounds in both maize cultivars. The potential of phenolics to act as an antioxidant is mainly due to their properties to act as hydrogen donators, reducing agents and quenchers of singlet $\mathrm{O}_{2}$ [20].

Application of Zn (II) HEDTA in maize plants grown in salinized nutrient solution led to accumulation of high amounts of antioxidant compounds as compared to that in plants grown without NaCl. The highest levels of TPC (6.05 and 4.30) mg G/gdw and TFC (2.80, 2.41) mgQ/gdw were observed in Single cross 10 (SC10) and Single cross162 (SC162) respectively. Leaf phenolic contents are important protective components of plant cells. Accumulation may have been due to the reason that the accumulation of phenolics depends on plant growth stage and may act in vivo through different mechanisms in plant stress tolerance [21] [22].

It is well known that, the higher concentrations of phenolics in Single cross 10 (SC10) can be explained by the accumulation of phenolic and flavonoids in stressed seedling of salt-tolerance Single cross 10 (SC10) than saltsensitive Single cross 162 (SC162) cultivar. Thus, flavonoids may have a protective role under stress conditions. Exogenous application of $\mathrm{Zn}$ counteracted the harmful effects of salinity on non-enzymatic scavenging systems. Application of Zn-Chelated increased the total phenols content in the leaves of two maize cultivars (Table 1 and Table 2). This has an adaptive significance, as it lowers the generation of free radicals and thus reduces the lipid peroxidation under salt stress. The reaction mechanisms by which the hydrogen atoms of phenol is transferred to a radical can be in two distinct pathways hydrogen atoms transfer and proton-coupled electron transfer [23].

Table 1. Effect of spraying $20 \mu \mathrm{mol}$ chelated zinc (Zn-HEDTA) on total phenols and flavonoids in methanolic of single cross 10 (SC10) cultivar in presence or absence of $100 \mathrm{mmol} \mathrm{NaCl}$.

\begin{tabular}{ccc}
\hline & Single cross 10 (SC10) & \\
\hline Treatment & TPC $\mathbf{~ m g} / \mathbf{g}$ & TFC $\mathbf{~ m g} / \mathbf{g}$ \\
\hline Control & $2.83^{\mathrm{a}} \pm 0.04$ & $1.52^{\mathrm{a}} \pm 0.09$ \\
NaCl & $4.62^{\mathrm{c}} \pm 0.03$ & $2.17^{\mathrm{b}} \pm 0.11$ \\
Control + Zn-Ch & $4.39^{\mathrm{b}} \pm 0.05$ & $2.11^{\mathrm{b}} \pm 0.11$ \\
NaCl + Zn-Ch & $6.05^{\mathrm{d}} \pm 0.04$ & $2.80^{\mathrm{c}} \pm 0.12$ \\
LSD (0.05) & 0.15 & 0.36 \\
\hline
\end{tabular}

All values with the same letter are not significantly different at $\mathrm{p}>0.05$; All values are the mean of three replicates \pm SD.

Table 2. Effect of spraying $20 \mu \mathrm{mol}$ chelated zinc (Zn-HEDTA) on total phenols and flavonoids in methanolic of single cross 162 (SC162) cultivar in presence or absence of $100 \mathrm{mmol} \mathrm{NaCl}$.

\begin{tabular}{ccc}
\hline & Single cross $\mathbf{1 6 2}$ (SC162) & \\
\hline Treatment & TPC $\mathbf{~ m g / g}$ & TFC $\mathbf{~ m g} / \mathbf{g}$ \\
\hline Control & $2.55^{\mathrm{a}} \pm 0.05$ & $1.28^{\mathrm{a}} \pm 0.07$ \\
$\mathbf{N a C l}$ & $7.03^{\mathrm{d}} \pm 0.06$ & $3.06^{\mathrm{d}} \pm 0.15$ \\
Control + Zn-Ch & $3.91^{\mathrm{b}} \pm 0.08$ & $1.85^{\mathrm{b}} \pm 0.14$ \\
NaCl + Zn-Ch & $4.38^{\mathrm{c}} \pm 0.06$ & $2.41^{\mathrm{c}} \pm 0.16$ \\
LSD (0.05) & 0.19 & 0.39 \\
\hline
\end{tabular}

All values with the same letter are not significantly different at $\mathrm{p}>0.05$; All values are the mean of three replicates \pm SD. 
Generally, this study showed that the levels of phenolic and flavonoids content in maize cultivars were comparable to previous findings in several varieties of wheat located in Asia and North America [8].

However, it is know that varieties, agronomic, the part of the sampled and environmental factors had significant effect on the concentrations of antioxidant compounds in maize plant [24].

\subsection{Effect of Salinity on Radical Scavenging Activity DPPH· on Two Maize Cultivars Spraying with Zn (II) HEDTA}

Free radical scavenging ability of methanolic extracts of the two cultivars of maize salinized plants in response to Zn (II) HEDTA foliar spray was measured with the change of absorbance caused by the reduction of DPPH radical, and results of the values of $\mathrm{IC}_{50}$ are shown in (Figure 1). It was clear that the leaves methanolic extracts showed significant scavenging activities with various degrees ( $\mathrm{IC}_{50}$ values ranged from $(24.2$ to $105.5 \mu \mathrm{g} / \mathrm{mL}$ ). The highest scavenging activity ( $\leq 0.5 \%$ ) was found for both cultivars extracts grown with $100 \mathrm{mmol} \mathrm{NaCl}$ combined with Zn (II) HEDTA foliar spray (97.82\% and 91.58\%) compared with that of synthetic antioxidant BHT (65.59\% and 68.59\%).

\subsection{Effect of Salinity on $\mathrm{Fe}^{2+-}$ Chelating Activity on Two Maize Cultivars Spraying with Zn (II) HEDTA}

The methanolic extracts of two maize cultivars grown with $\mathrm{NaCl}$ combined with foliar spray of Zn (II) HEDTA exhibited appreciable Iron-chelating activity. The highest Fe-chelating activity were observed for extracts of Single cross 10 (SC10) stressed plants treated with Zn (II) HEDTA foliar spray ranged from (43.73 to 54.64 $\mu \mathrm{g} / \mathrm{ml}$ ) (Table 3), followed by Single cross 162 (SC162) ranged from (40.39 to $58.66 \mu \mathrm{g} / \mathrm{ml}$ ) (Table 4). This

(a)

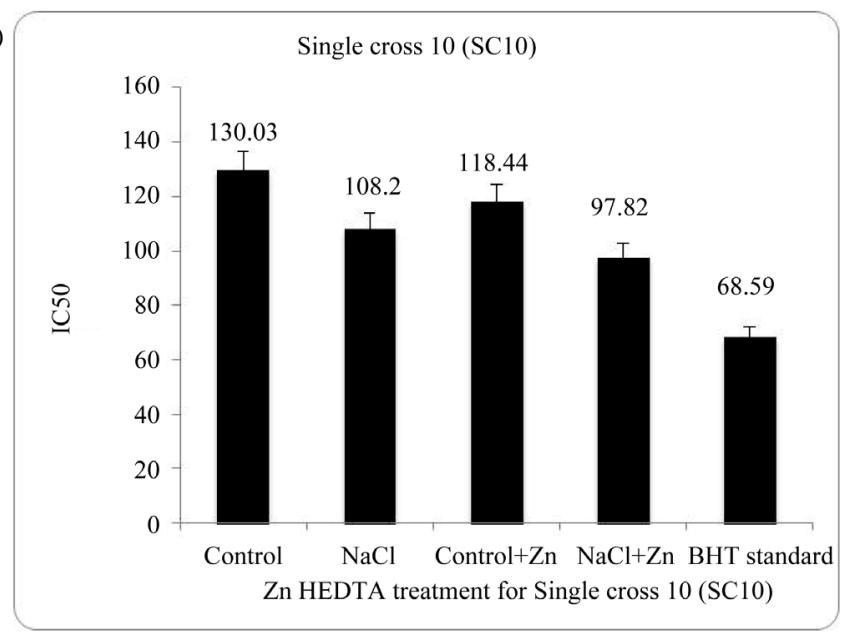

(b)

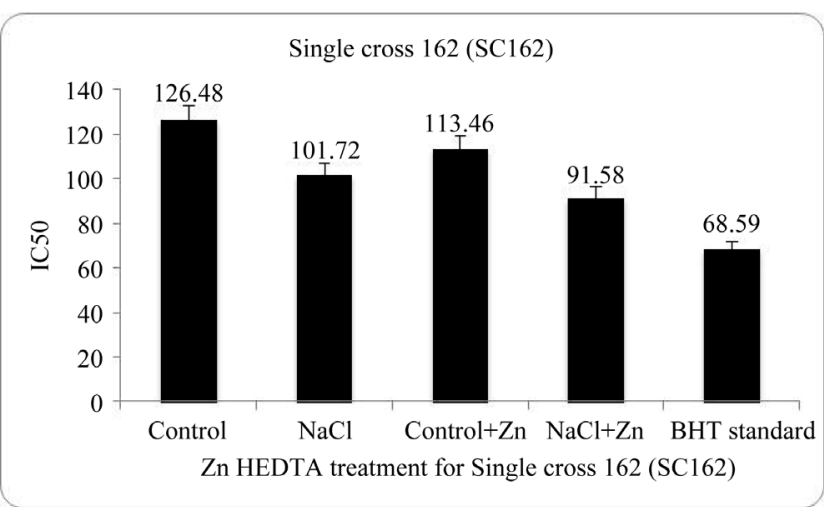

Figure 1. $\mathrm{IC}_{50}$ of leaves methanolic extract of Single cross 10 (SC10) (a) and Single cross 162(SC162) (b) in presence or absence $100 \mathrm{mmol}$ $\mathrm{NaCl}$ spraying with $20 \mu \mathrm{mol} Z \mathrm{Zn}$ HEDTA. 
Table 3. Effect of spraying $20 \mu \mathrm{mol}$ zinc HEDTA on iron chelating activity of leaves methanolic extracts of Single cross 10 (SC10) cultivar in presence or absence $100 \mathrm{mmol} \mathrm{NaCl}$.

\begin{tabular}{cccccc}
\hline & \multicolumn{5}{c}{ Inhibition \% } \\
\hline Treatments & $20 \mu \mathrm{g} / \mathrm{ml}$ & $50 \mu \mathrm{g} / \mathrm{ml}$ & $100 \mu \mathrm{g} / \mathrm{ml}$ & $150 \mu \mathrm{g} / \mathrm{ml}$ & $200 \mu \mathrm{g} / \mathrm{ml}$ \\
\hline Control & $4.72^{\mathrm{a}} \pm 0.48$ & $11.45^{\mathrm{a}} \pm 0.18$ & $23.38^{\mathrm{a}} \pm 0.38$ & $31.67^{\mathrm{a}} \pm 0.36$ & $42.73^{\mathrm{a}} \pm 0.54$ \\
$\mathrm{NaCl}$ & $7.37^{\mathrm{c}} \pm 0.36$ & $15.70^{\mathrm{c}} \pm 0.24$ & $26.71^{\mathrm{c}} \pm 0.30$ & $38.25^{\mathrm{c}} \pm 0.30$ & $51.64^{\mathrm{c}} \pm 0.25$ \\
Control + Zn-Ch & $6.30^{\mathrm{b}} \pm 0.36$ & $13.32^{\mathrm{b}} \pm 0.36$ & $24.34^{\mathrm{b}} \pm 0.30$ & $34.48^{\mathrm{b}} \pm 0.24$ & $47.52^{\mathrm{b}} \pm 0.30$ \\
NaCl + Zn-Ch & $9.24^{\mathrm{d}} \pm 0.30$ & $18.51^{\mathrm{d}} \pm 0.42$ & $29.42^{\mathrm{d}} \pm 0.28$ & $40.39^{\mathrm{d}} \pm 0.48$ & $54.46^{\mathrm{d}} \pm 0.24$ \\
EDTA standard & $42.41^{\mathrm{e}} \pm 0.30$ & $63.50^{\mathrm{e}} \pm 0.43$ & $75.51^{\mathrm{e}} \pm 0.36$ & $82.80^{\mathrm{e}} \pm 0.42$ & $91.56^{\mathrm{e}} \pm 0.24$ \\
LSD (0.05) & 0.70 & 0.43 & 0.56 & 0.61 & 0.65 \\
\hline
\end{tabular}

All values with the same letter are not significantly different at $\mathrm{p}>0.05$; All values are the mean of three replicates \pm SD.

Table 4. Effect of spraying $20 \mu \mathrm{mol}$ zinc HEDTA on iron chelating activity of leaves methanolic extracts of Single cross 162 (SC162) cultivar in presence or absence $100 \mathrm{mmol} \mathrm{NaCl}$.

\begin{tabular}{cccccc}
\hline & \multicolumn{5}{c}{ Inhibition \% } \\
\hline Treatments & $20 \mu \mathrm{g} / \mathrm{ml}$ & $50 \mu \mathrm{g} / \mathrm{ml}$ & $100 \mu \mathrm{g} / \mathrm{ml}$ & $150 \mu \mathrm{g} / \mathrm{ml}$ & $200 \mu \mathrm{g} / \mathrm{ml}$ \\
\hline Control & $3.37^{\mathrm{a}} \pm 0.30$ & $9.16^{\mathrm{a}} \pm 0.36$ & $19.74^{\mathrm{a}} \pm 0.24$ & $28.50^{\mathrm{a}} \pm 0.48$ & $40.39^{\mathrm{a}} \pm 0.48$ \\
$\mathrm{NaCl}$ & $8.56^{\mathrm{c}} \pm 0.24$ & $17.48^{\mathrm{c}} \pm 0.31$ & $26.75^{\mathrm{c}} \pm 0.36$ & $39.79^{\mathrm{c}} \pm 0.18$ & $53.31^{\mathrm{c}} \pm 0.48$ \\
Control + Zn-Ch & $5.35^{\mathrm{b}} \pm 0.31$ & $11.49^{\mathrm{b}} \pm 0.42$ & $24.65^{\mathrm{b}} \pm 0.30$ & $33.57^{\mathrm{b}} \pm 0.36$ & $47.52^{\mathrm{b}} \pm 0.30$ \\
NaCl + Zn-Ch & $9.27^{\mathrm{d}} \pm 0.54$ & $20.49^{\mathrm{d}} \pm 0.42$ & $32.82^{\mathrm{d}} \pm 0.36$ & $46.37^{\mathrm{d}} \pm 0.24$ & $58.66^{\mathrm{d}} \pm 0.36$ \\
EDTA standard & $42.41^{\mathrm{e}} \pm 0.30$ & $63.50^{\mathrm{e}} \pm 0.43$ & $75.51^{\mathrm{e}} \pm 0.36$ & $82.80^{\mathrm{e}} \pm 0.42$ & $91.56^{\mathrm{e}} \pm 0.24$ \\
LSD (0.05) & 0.68 & 0.77 & 0.54 & 0.60 & 0.71 \\
\hline
\end{tabular}

All values with the same letter are not significantly different at $\mathrm{p}>0.05$; All values are the mean of three replicates \pm SD.

finding was in accordance with [8] who found that the alcoholic extracts of a wheat variety grown in different locations (Canadian and Pakistanis), showed good antioxidant activity with various degrees.

\subsection{Correlation}

TPC and TFC exhibited a positive correlation with antioxidant scavenging properties $\left(\mathrm{IC}_{50}\right)$ and $\mathrm{Fe}^{2+}$-chelating. Correlation coefficient of TPC, and TFC as well as DPPH' scavenging assay and Fe chelating for both cultivars (Figure 2 \& Figure 3). For Single cross 10(SC10) total phenolics (TPC) are correlated with IC50 $\left(R^{2}=0.9452\right.$ (Figure 2(a)) and (TFC) are correlated with IC50 $\left(R^{2}=0.9298\right)$ (Figure 2(b)). Positive correlation coefficient between TPC, TPC and Fe chelating activity was observed $\left(R^{2}=0.8671\right)$ (Figure 2(c)) and $\left(R^{2}=0.8691\right.$ ) (Figure 2(d)) of Single cross 10 (SC10) respectively. The antioxidant activity of phenolics is mainly due to their redox properties, which allow them to act as reducing agents, hydrogen donors, and singlet oxygen quenchers [20]. The correlation coefficient between $\mathrm{IC}_{50}$ and total phenolic content (TPC), total flavonoid content (TFC), of Single cross 162 (SC162) is shown in (Figure 3). Results given in (Figure 3) showed that TPC are highly correlated with IC50 $R^{2}=0.8914$ (Figure 3(a)) and TFC $R^{2}=0.9926$ (Figure 3(b)). Correlation between $\mathrm{Fe}^{2+}$ chelating activity at concentration $200 \mu \mathrm{g} / \mathrm{ml}$ and TPC had a very strong correlation coefficient $R^{2}=0.9782$ (Figure 3(c)), $R^{2}=0.9785$ with flavonoids content (Figure 3(d)). The results revealed that TPC, TFC strongly contributed to the antioxidant scavenging activity of maize methanolic extracts. These findings further supported the positive relationship between TP, TF and antioxidant activity of different plant species. It has been found that strong positive relationship between TP and antioxidant activity that appears to be the trend in many plant species [25] [26].

\section{Conclusion}

Based on the results obtained, it might be concluded that foliar application of Zn (II) HEDTA improved the physiological and biochemical performance of maize plants in terms of increasing antioxidant compounds. 


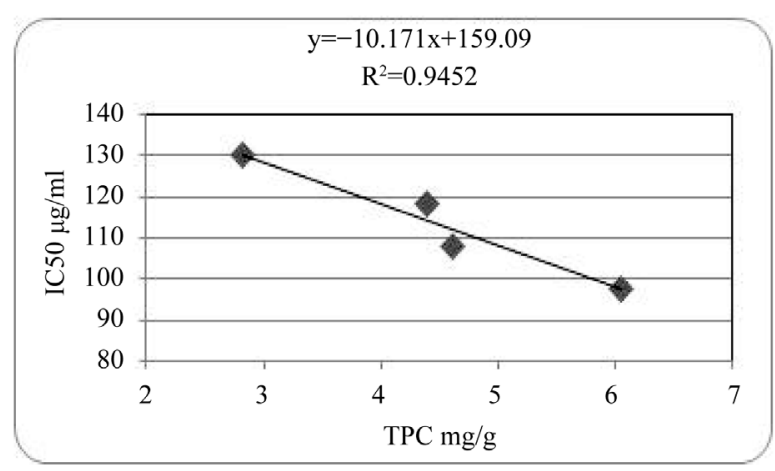

(a)

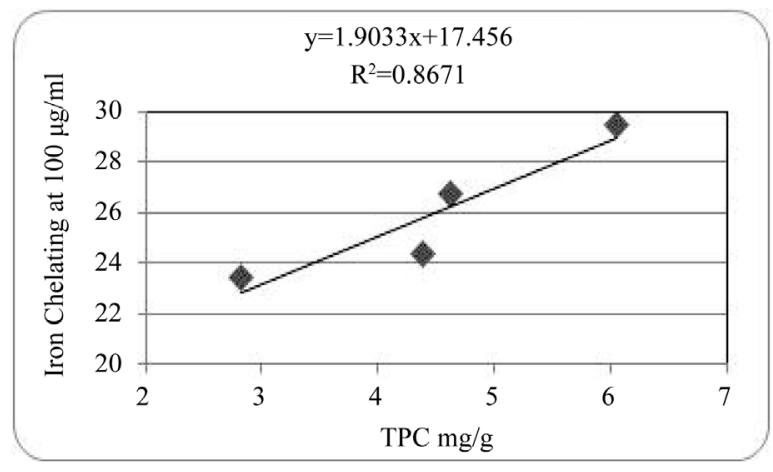

(c)

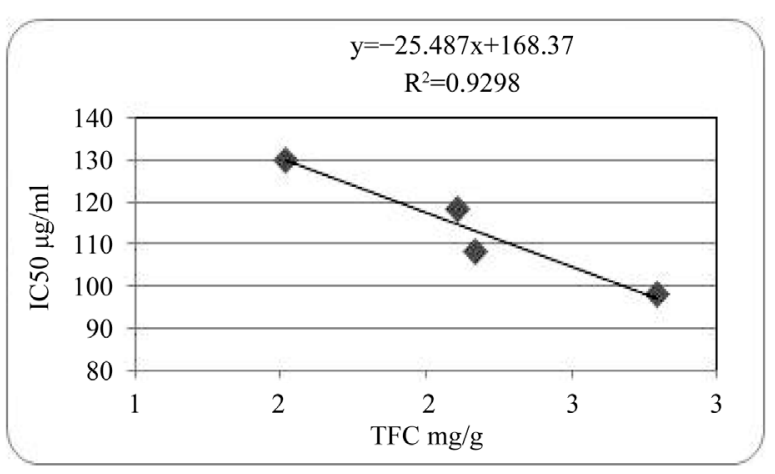

(b)

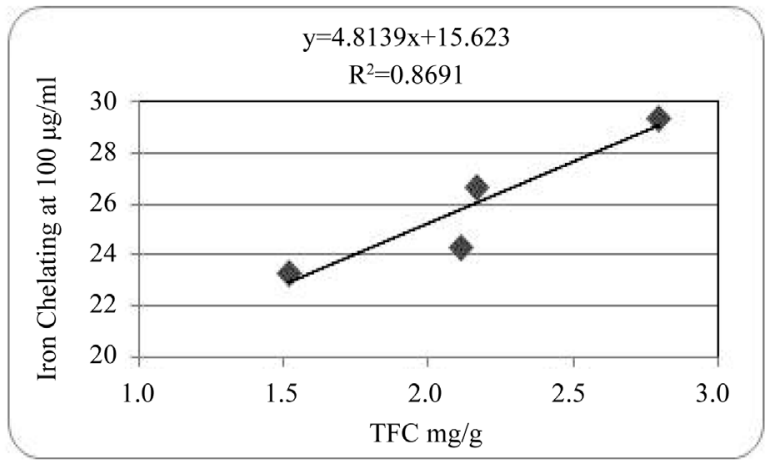

(d)

Figure 2. Correlation between $\mathrm{IC}_{50}$ and phenolics (a), flavonoids (b) and Iron chelating at (100 $\left.\mu \mathrm{g} / \mathrm{ml}\right)$ and phenolics (c) and flavonoids (d) of Single cross 10 (SC10) spraying with $20 \mu \mathrm{mol}$ zinc HEDTA in presence or absence of $100 \mathrm{mmol} \mathrm{NaCl}$.

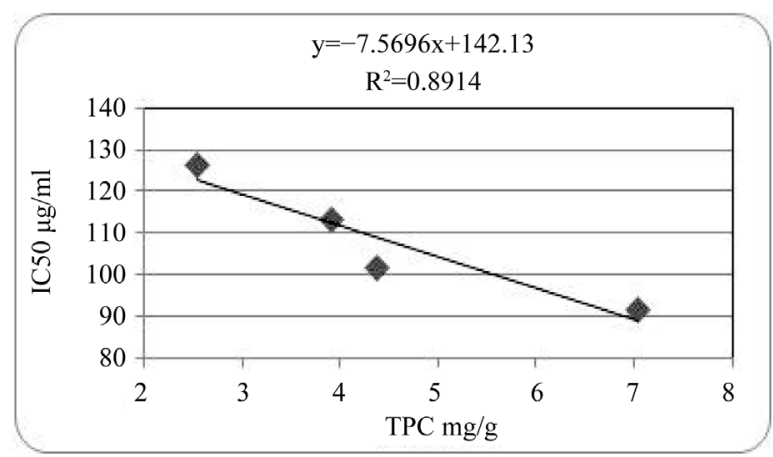

(a)

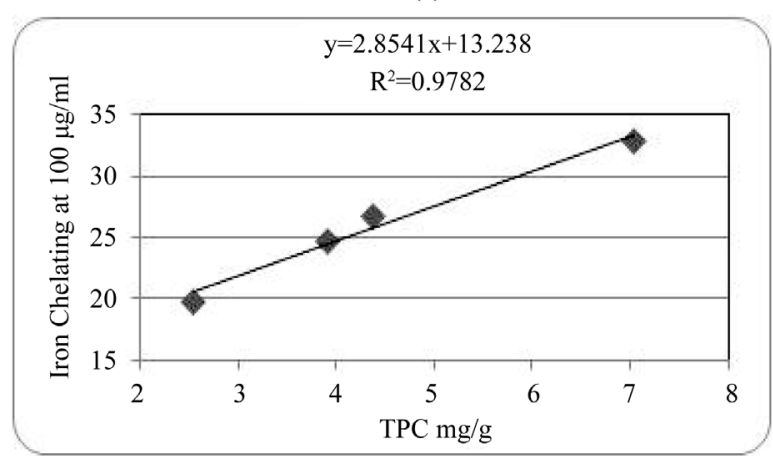

(c)

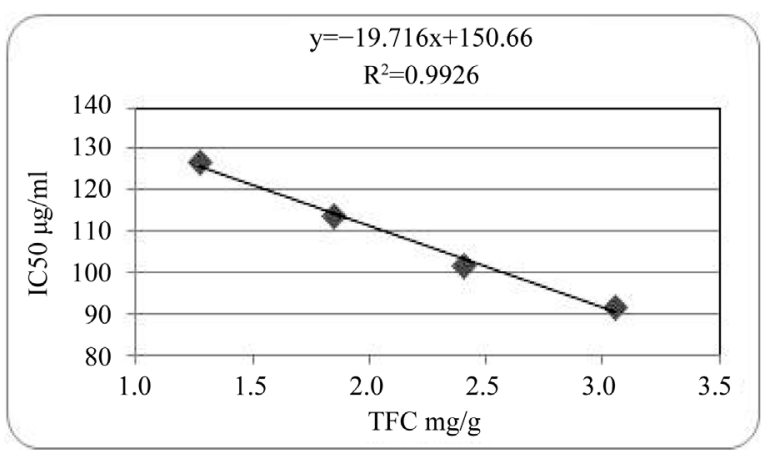

(b)

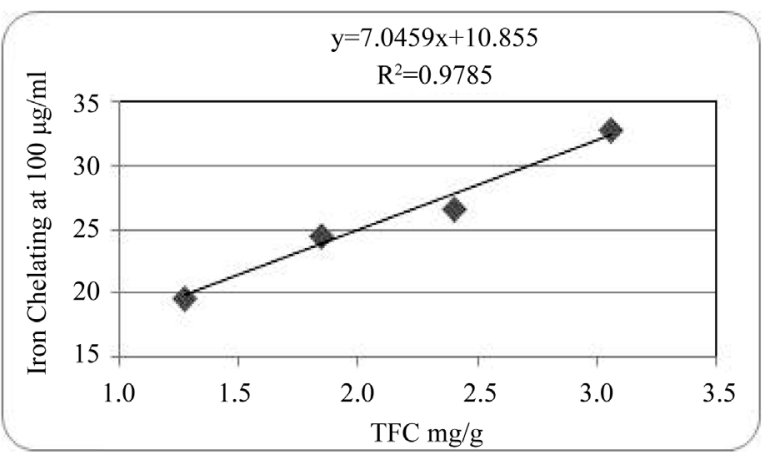

(d)

Figure 3. Correlation between $\mathrm{IC}_{50}$ and phenolics (a), flavonoids (b) and iron chelating at (100 $\left.\mu \mathrm{g} / \mathrm{ml}\right)$ and phenolics (c), flavonoids (d) of Single cross 162 (SC162) cultivar spraying with $20 \mu \mathrm{mol}$ zinc HEDTA in presence or absence of $100 \mathrm{mmol} \mathrm{NaCl}$. 


\section{Acknowledgements}

This work was done in the frame of the cooperation between National Research Centre (NRC) and Popov Institute for Plant Physiology Sofia-Belgaria (Egyptian Academy of Science and Technology-Bulgarian Academy of Science). It was supported by the Egypto-German Project "Micronutrient and other Plant Nutrition Problems "implemented by the National Research Centre (NRC) The project was supported by the Egyptian Academy of Science and Technology and the German Federal Ministry of Technical Cooperation (BMZ) through the German Agency For Technical Cooperation (GTZ).

\section{References}

[1] Yousfi, S., Wissal, M., Mahmoudi, H., Abdely, C. and Gharsalli, M. (2007) Effect of Salt on Physiological Responses of Barley to Iron Deficiency. Plant Physiology and Biochemistry, 45, 309-314. http://dx.doi.org/10.1016/j.plaphy.2007.03.013

[2] Daneshbakhsh, B., Khoshgoftarmanesh, A.H., Shariatmadari, H. and Cakmak, I. (2013) Phytosiderophore Release by Wheat Genotypes Differing in Zinc Deficiency Tolerance Grown with Zn-Free Nutrient Solution as Affected by Salinity. Journal of Plant Physiology, 170, 41-46. http://dx.doi.org/10.1016/j.jplph.2012.08.016

[3] El-Fouly, M.M., Mobarak, Z.M. and Salama, Z.A. (2011) Micronutrients (Fe, Mn, Zn) Foliar Spray for Increasing Salinity Tolerance in Wheat Triticum aestivum L. African Journal of Plant Science, 5, 314-322.

[4] Posmyk, M.M., Kontek, R. and Janas, K.M. (2009) Antioxidant Enzymes Activity and Phenolic Compounds Content in Red Cabbage Seedlings Exposed to Copper Stress. Ecotoxicology and Environmental Safety, 72, 596-602. http://dx.doi.org/10.1016/j.ecoenv.2008.04.024

[5] Tsai, P.J., Mc-Instosh, J., Pearce, P., Camden, B. and Jordan, B.R. (2002) Anthocyanin and Antioxidant Capacity in Roselle (Hibiscus sabdariffa L.) Extract. Food Research International, 35, 351-356. http://dx.doi.org/10.1016/S0963-9969(01)00129-6

[6] Wang, Y. and Nil, N. (2000) Changes in Chlorophyll, Ribulose Biphosphate Carboxylase-Oxygenase, Glycine Betaine Content, Photosynthesis and Transpiration in Amaranthus tricolor Leaves during Salt Stress. Journal of Horticultural Science and Biotechnology, 75, 623-627.

[7] Rice-Evans, C.A., Miller, N.J. and Paganga, G. (1996) Structure-Antioxidant Activity Relationships of Flavonoids and Phenolic Acids. Free Radical Biology and Medicine, 20, 933-956. http://dx.doi.org/10.1016/0891-5849(95)02227-9

[8] Iqbal, M. and Ashraf, M. (2006) Wheat Seed Priming in Relation to Salt Tolerance, Growth, Yield and Level of Free Salicylic Acid and Polyamines. Annales Botanici Fennici, 43, 250-259.

[9] Fardet, A., Rock, E. and Christian, R. (2008) Is the in Vitro Antioxidant Potential of Whole-Grain Cereals and Cereal Products Well Reflected in Vivo. Journal of Cereal Science, 48, 258-276. http://dx.doi.org/10.1016/j.jcs.2008.01.002

[10] Zhou, K., Laux, J.J. and Yu, L. (2004) Comparison of Swiss Red Wheat Grain and Fractions for Their Antioxidant Properties. Journal of Agricultural and Food Chemistry, 52, 1118-1123. http://dx.doi.org/10.1021/jf030640w

[11] Liu, R.H. (2007) Whole Grain Phytochemicals and Health. Journal of Cereal Science, 46, 207-219. http://dx.doi.org/10.1016/j.jcs.2007.06.010

[12] Alpaslan, M., Inal, A., Gunes, A., Cikili, Y. and Ozcan, H. (1999) Effect of Zinc Treatment on the Alleviation of Sodium and Chloride Injury in Tomato (Lycopersicum esculentum (L.) Mill. cv. Lale) Grown under Salinity. Turkish Journal of Botany, 23, 1-6.

[13] El-Fouly, M.M. and Salama, Z.A. (1999) Can Foliar Fertilization Increase Plant Tolerance to Salinity? Proc. Dahlia Greidinger Intern. Symp. Nutrient Management under Salinity and Water Stress, 3, 113-125.

[14] Salama, Z.A., El Fouly, M.M. and Gaafar, A.A. (2013) Mitigation of the Adverse Effect of Salinity through Stimulation Some Secondary Metabolites and Antioxidant Enzymes of Methanolic Extract of Maize Cultivars by Exogenous Ascorbic Acid. Journal of Food, Agriculture and Environment, 11, 1328-1335.

[15] Singleton, V.L. and Rossi Jr., J.A. (1965) Colorimetric of Total Phenolics with Phosphomolybdic-Phosphotungstic Acid Reagents. American Journal of Enology and Viticulture, 16, 144-158.

[16] Jia, Z.S., Tang, M.C. and Wu, J.M. (1999) The Determination of Flavonoid Contents in Mulberry and Their Scavenging Effects on Superoxide Radicals. Food Chemistry, 64, 555-559. http://dx.doi.org/10.1016/S0308-8146(98)00102-2

[17] Chu, Y.H., Chang, C.L. and Hsu, H.F. (2000) Flavonoid Content of Several Vegetables and Their Antioxidant Activity. Journal of the Science of Food and Agriculture, 80, 561-566. http://dx.doi.org/10.1002/(SICI)1097-0010(200004)80:5<561::AID-JSFA574>3.0.CO;2-\#

[18] Hsu, C., Chen, W., Weng, Y. and Tseng, C. (2003) Chemical Composition, Physical Properties, and Antioxidant Ac- 
tivities of Yam Flours as Affected by Different Drying Methods. Food Chemistry, 83, 85-92. http://dx.doi.org/10.1016/S0308-8146(03)00053-0

[19] Anonymous, A. (2009) Cohort Software. 1986. Costat User’s Manual Virgin 3.03. Berkley, California, USA.

[20] Rice-Evans, C., Miller, N. and Paganga, G. (1997) Antioxidant Properties of Phenolic Compounds. Trends in Plant Science, 2, 152-159. http://dx.doi.org/10.1016/S1360-1385(97)01018-2

[21] Choi, Y., Jeong, H.S. and Lee, J. (2007) Antioxidant Activity of Methanolic Extracts from Some Grains Consumed in Korea. Food Chemistry, 103, 130-138. http://dx.doi.org/10.1016/j.foodchem.2006.08.004

[22] Barros, L., Baptista, P. and Ferreira, I.C.F.R. (2007) Effect of Lactarius piperatus Fruiting Body Maturity Stage on Antioxidant Activity Measured by Several Biochemical Assays. Food and Chemical Toxicology, 45, 1731-1737. http://dx.doi.org/10.1016/j.fct.2007.03.006

[23] Mittler, R. (2002) Oxidative Stress, Antioxidants and Stress Tolerance. Trends in Plant Science, 7, 405-410. http://dx.doi.org/10.1016/S1360-1385(02)02312-9

[24] Adom, K.K., Sorrells, M. and Liu, R.H. (2005) Phytochemicals and Antioxidant Activity of Milled Fractions of Different Wheat Varieties. Journal of Agricultural and Food Chemistry, 53, 2297-2306. http://dx.doi.org/10.1021/jf048456d

[25] Ghasemzadeh, A., Azarifar, M., Soroodi, O. and Jaafar, H.Z.E. (2012) Flavonoid Compounds and Their Antioxidant Activity in Extract of Some Tropical Plants. Journal of Medicinal Plants Research, 6, 2639-2643.

[26] El-Fouly, M.M., Mobarak, Z.M. and Salama, Z.A. (2010) Improving Tolerance of Faba Bean during Early Growth Stages to Salinity through Micronutrients Foliar Spray. Not Sci Biol, 2, 98-102. 